\title{
RICE MARKET INFORMATION TRANSFER SYSTEM (MITS) IN THE MEKONG DELTA, VIETNAM?
}

\author{
Pham Cong NGHIEP
}

\author{
PhD student \\ Enyedi György Doctoral School of Regional Sciences, Faculty of Economics and Social \\ Sciences, Szent István University \\ E-mail:pc_nghiep@yahoo.com
}

\begin{abstract}
MITS had an important role in farmers' production and trade. However, MITS in the Mekong delta, Vietnam was very weak. There were lacks of good sources and channels of market information, the market information was outdated, inaccurate and inadequate. In addition, farmers' ability and knowledge to collect, analyze and use market information were also limited. Therefore, the aims of the paper are to have a real clear picture about the current MITS in the rice value chain in the Mekong delta of Vietnam (rice farmer's demands of rice market information, sources of rice market information, channels of rice market information, rice market information utilization and impacts of MITS on rice farmers in the Mekong delta, Vietnam). This paper gives an overview about 15 structural interviews made with 15 rice farmers in the Mekong delta, Vietnam. The findings of this study show that rice farmers in the Mekong delta, Vietnam have been accessing and using market information from formal and informal sources (Governmental agencies, traders, farmers, and mass media) via 7 main channels (Television, newspaper, radio, Internet, phone, face-to-face meetings, loudspeaker) to increase the selling prices, rice income, to decrease the risks in rice production and trade and to improve negotiation ability of farmers with traders.
\end{abstract}

Kulcsszavak: Rice production, market information, farmers, qualitative study, Vietnam JEL besorolás: Q13

LCC: SB109.7-111

\section{Introduction}

Rice has an important role in Vietnamese life and economy. According to General Statistics Office (GSO) rice subsector occupied $40 \%$ of gross output of the Vietnamese agriculture, 9.3 million households have been planting paddy (65\% of rural households) and over $70 \%$ of the national labor force were employed in rice production. According to GSO, during the period of 2007 to 2013 Vietnam exported 6.265 million tons of rice on average with its value of 2.936 billion USD per year.

The Mekong delta is the rice granary in Vietnam. This region has contributed to the national rice output up to $50 \%$ and the rice export up to $90 \%$. However, the main issue in rice sector is that in the Mekong delta there is a low profit for rice farmers. According to a study by Tran Cong Thang, Do Lien Huong, Le Nguyet Minh in 2013 the average income of rice farmers from rice production in the Mekong delta was very low with $535,000 \mathrm{VND} / \mathrm{month}$ (about 25USD/month).

Market information system plays an important role in raising the efficiency of economic performance and it helps farmers enter the market better, sell more products at higher prices 
(Sultan Freihat, 2012). Nowadays farmers in the developing countries like Vietnam do not have much good market information to make the accurate decisions in their production and trade.

The demand of improving the market information system is imperative and it has a great significance to rice farmers in the Mekong delta, Vietnam. The competitive pressure of rice farmers in the Mekong delta is growing because with the development of science and technology they have produced more and more the rice output. As a result, many rice farmers need to sell a bigger amount at the same time and so they need to find larger markets to sell the higher amount of rice with higher prices. There are more and more mediators between rice farmers and final customers as well as export companies in the Mekong delta and these mediators became a barrier for the market information flow in the rice value chain, even they can distort the market information to get advantages in the bargain making a wider gap of market information among participants in the rice value chain. Therefore my research will help us have a clear insight into the current MITS in the rice value chain in the Mekong delta, Vietnam in order to propose a model of MITS that is suitable in the Vietnamese condition, in a developing country, with low income and weak infrastructure.

And lastly, there are few researches and information on MITS in Vietnam so we do not know the strengths and the weaknesses of MITS, how to improve the MITS to meet the market information demand of rice farmers. Those are the reasons why I performed this study.

\section{Market information transfer system (MITS)}

A market information transfer system contains 4 elements: Market information, source, channel and receiver. In this study the receiver means the rice farmers in the Mekong delta, Vietnam.

Market information is an essential factor in MITS, it determines the effectiveness of the whole system. Many researchers defined market information as follows: Market information includes market news (information on prices, quantities, market conditions, and business contacts), market analytical reports (reports that analyze factors that cause changes in market conditions and their effects on stakeholders), and business reports (providing information that can help stakeholders identify reliable trade partners).

The market information source is a very important part in MITS because information sources will affect so much the quality of information farmers will get. Information source is an institution or an individual that creates or brings about a message (Starasts, A. M., 2004) and hence, there are many kinds of different sources: media, radio, TV, personal experience, books, journals and magazine articles, expert opinions, internet, extension agents, etc.

Farmers can access to market information from many different sources and in fact, farmers used multiple sources of market information to access to the market information because they usually did not find any single source providing all that they need and these sources had various reliability and accuracy (Surabhi Mittal and Mamta Mehar, 2013). There were 2 kinds of formal and informal sources of market information for farmers (Edda Tandi Lwoga and et al, 2010). The informal sources constitute face-to-face interactions with friends, relatives, other farmers, and traders or mass media when mass media get the market information from informal sources to transfer to farmers. On the other hand, formal sources refer to the information that is created specifically for farmers by governmental agencies such as extension agents, local authorities, by NGOs or by mass media when media uses market information from formal sources to transfer to farmers. Farmers used a combination of these formal and informal sources to access to information simultaneously (Surabhi Mittal and Mamta Mehar, 2013). However, farmers 
mainly seek to obtain knowledge and information from informal sources rather than formal ones (Edda Tandi Lwoga, et al, 2010). A study of Saikia S. and Barman U. (2013) on 120 rice farmers in India indicated that only $6.67 \%$ of rice growers accessed market information from the extension agents and about $52.94 \% ; 17.64 \%$ and $22.55 \%$ of rice growers accessed market information from their neighbors, family members and friends, respectively. In Zambia almost all farmers obtained information from personal experience, and informal networks (family, friends, and colleagues) to meet their information needs (Trywell Kalusopa, 2005).

Market information channel is means that market information providers use to transfer market information to receivers (farmers). Market information providers should use simple vehicles to transfer information because with these simple vehicles market information receivers (farmers) may access to and use information at low costs. With the development of information technology market information providers and receivers have many options to choose vehicles to disseminate and receive the market information.

\section{Material and methods}

This research is the first stage in my PhD study. Due to MITS is a new topic for Vietnam and for me and therefore I used the qualitative method to fast gather information and the secondary data on various aspects of the study, organize a fieldwork plan, and make the questionnaire for the final survey in the second stage (the quantitative research) and so on. This interview also provided a chance to understand MITS in the Mekong delta.

\section{Research area}

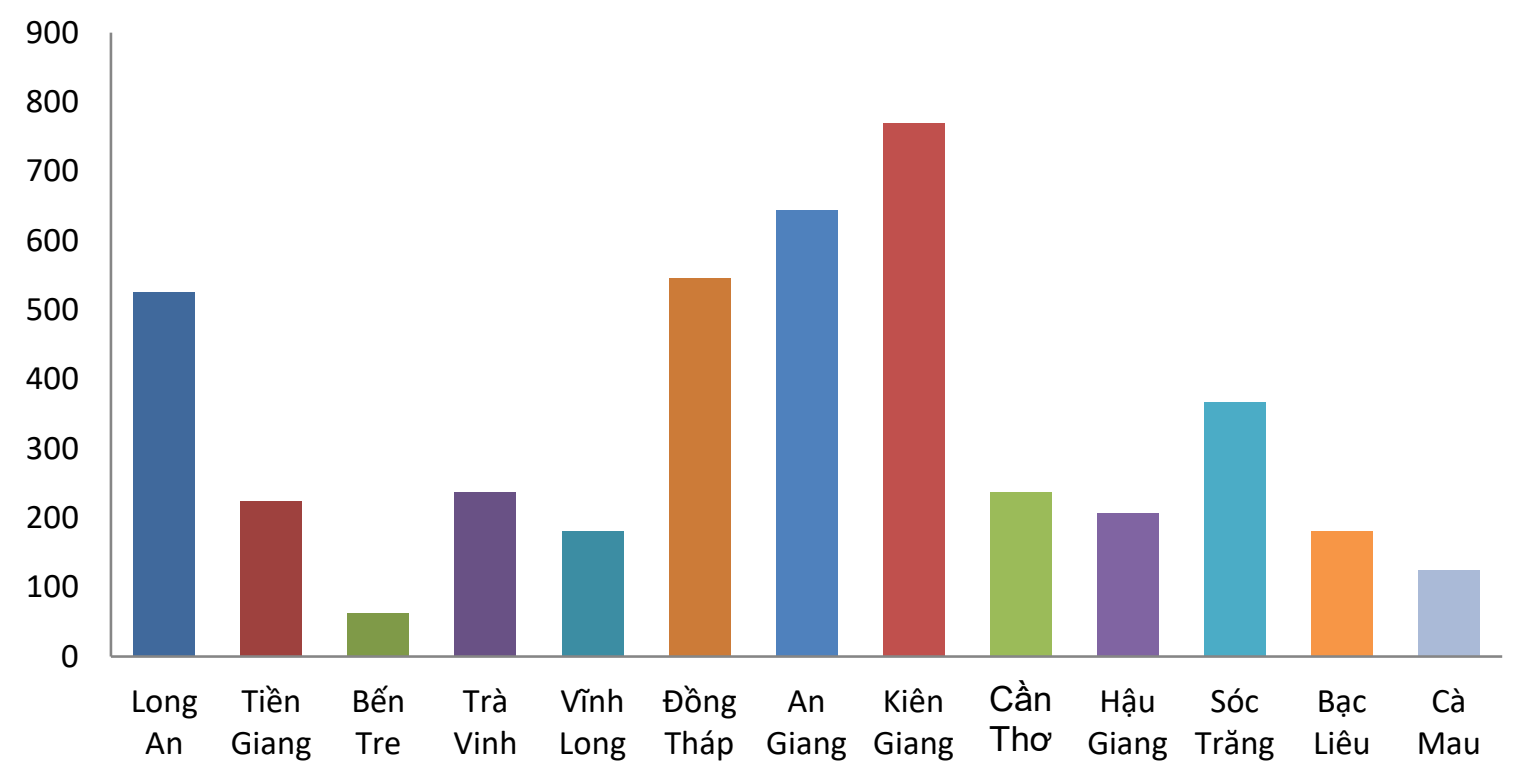

Figure 1: Area of rice production in the Mekong delta by provinces in 2015 (1000ha) Source: GSO, 2016

I chose An Giang province as a research area in this survey because An Giang province is a top rice producer in the Mekong delta (see figure 1) so rice farmers in An Giang have a high demand of market information. In An Giang province, thanks to the advice of the leader of Agricultural Extensions Center of An Giang I chose 3 districts to survey, in which there is a district with a large area of rice production (Thoai Son district), a district with a medium area of rice production (Chau Phu district) and a district with a small area of rice production (Cho Moi 
district). In each district, I randomly chose 5 farmers including advanced farmers, large-scale farmers and non-advanced farmers, as well as small-scale farmers to interview.

\section{Sample size}

According to Mária Bernschütz (2011), the researcher can work with a sample of small numbers, there is no need for a big sample in qualitative methodology. Therefore I interviewed with the size of research sample of 15 rice farmers. Besides, I talked to the director of Agricultural Extension Center of An Giang to understand the current MITS in the Mekong delta, Vietnam.

\section{Questions of structural interview}

I used the guide to interview rice farmers in An Giang. The guide contained 2 main parts: (1) MITS (farmer's demands of rice market information, sources of rice market information, channels of rice market information and rice market information utilization) (2) the impacts of MITS on rice farmers in the Mekong delta of Vietnam.

\section{Analyzing the interviews}

I recorded all 15 interviews and then typed the answers from those records to find the similarities and differences of rice farmers' answers for each question in the interview.

I putted anonyms of respondents into a bracket ( ) after their answers.

\section{Results}

\section{Rice farmers' demands for market information}

Determining the market information demand of farmers is very important because it will help a lot for us to propose the MITS model to accurately meet these demands.

Rice farmers in the Mekong delta need 2 kinds of rice market information: Macro-information and micro-information. The micro-information contains the following information: prices of each rice variety in their area what that help them have an orientation to grow rice varieties with a higher selling price; the phone number and the address of traders that help farmers have many chances to call traders to check the price information and then they will decide where to sell, whom to sell with the highest price. The macro-information includes the predictions about rice markets (market trends) to help farmers adjust their production plans to fit these market trends and information about rice export of Vietnam that helps farmers orient their market and investment in their rice production. If information about rice export of Vietnam indicates that rice export of Vietnam is advantageous, the export price of Vietnamese rice is high, rice farmers will increase investment in their rice fields to increase rice yield and quality to raise their profits and the opposite.

We need the detailed information to bargain with traders such as prices, traders' address, phone numbers to call them to ask and compare with information from other traders. In addition, we also concern about rice export of Vietnam because it will affect the rice prices on the domestic market. If rice export of Vietnam is good, the rice price will increase (A farmer in Chau Phu district). 
During my rice production, if I hear that the rice price increases, I will invest more in rice fields and also visit the rice fields more frequently to increase rice yield and quality. If I hear that the rice price reduces, I will limit investment into rice fields to reduce the production costs and to reduce loss (A farmer in Chau Phu district).

From the information about prices of different kinds of rice in some previous seasons we will know the rice variety which has a good price to grow and to increase the profit. My family replaced IR50404 by OM5451 with the higher price by 200-250 VND/kg (A farmer in Thoai Son district).

Table 1: The farmers' demands of rice market information in the Mekong delta

\begin{tabular}{|l|l|}
\hline \multirow{2}{*}{ Micro-information } & \multicolumn{1}{c|}{ Market information } \\
\hline \multirow{2}{*}{ Macro-information } & Prices of each rice variety \\
\cline { 2 - 2 } & Phone numbers of traders \\
\cline { 2 - 2 } & Addresses of traders \\
\cline { 2 - 2 } & Prediction of rice markets \\
\cline { 2 - 2 } & Rice export situation of Vietnam \\
\hline
\end{tabular}

Source: Own survey, 2016

It can be seen that there are differences in rice market information demands among rice farmers. Large-scale farmers and advanced farmers need both micro-information and macro-information because they can analyze and use 2 kinds of information for their rice production and trading, meanwhile small-scale farmers and non-advanced farmers often concern only microinformation.

\section{Sources and channels of rice market information}

Market information sources and channels are the most important elements in MITS. They influence the market information quality, information dissemination speed, the amount of market information receivers, etc. Diagram 1 presents MITS in the rice value chain in the Mekong delta, Vietnam. Rice farmers in the Mekong delta have been accessing to market information from 2 kinds of market information sources (Formal sources: Governmental agencies, newspaper, radio, etc and Informal source: Traders, farmers, internet, etc) through 7 kinds of market information channels (Television, newspaper, radio, Internet, phone, face-toface meetings, loudspeaker).

Rice farmers in the Mekong delta have been accessing to many different sources of market information simultaneously to compare and make decisions on their rice production and trade.

My family has accessed to many sources of market information such as friends, television, traders, etc to bargain with traders in an advantageous way (a farmer in Thoai Son district).

Based on the market information needs the farmer will choose the sources of the market information. Farmers got macro-information mainly from TV (national TV) or few farmers could get from Agriculture Newspaper of Vietnam and Internet. For micro-information they directly accessed to sources such as traders, farmers, etc. 


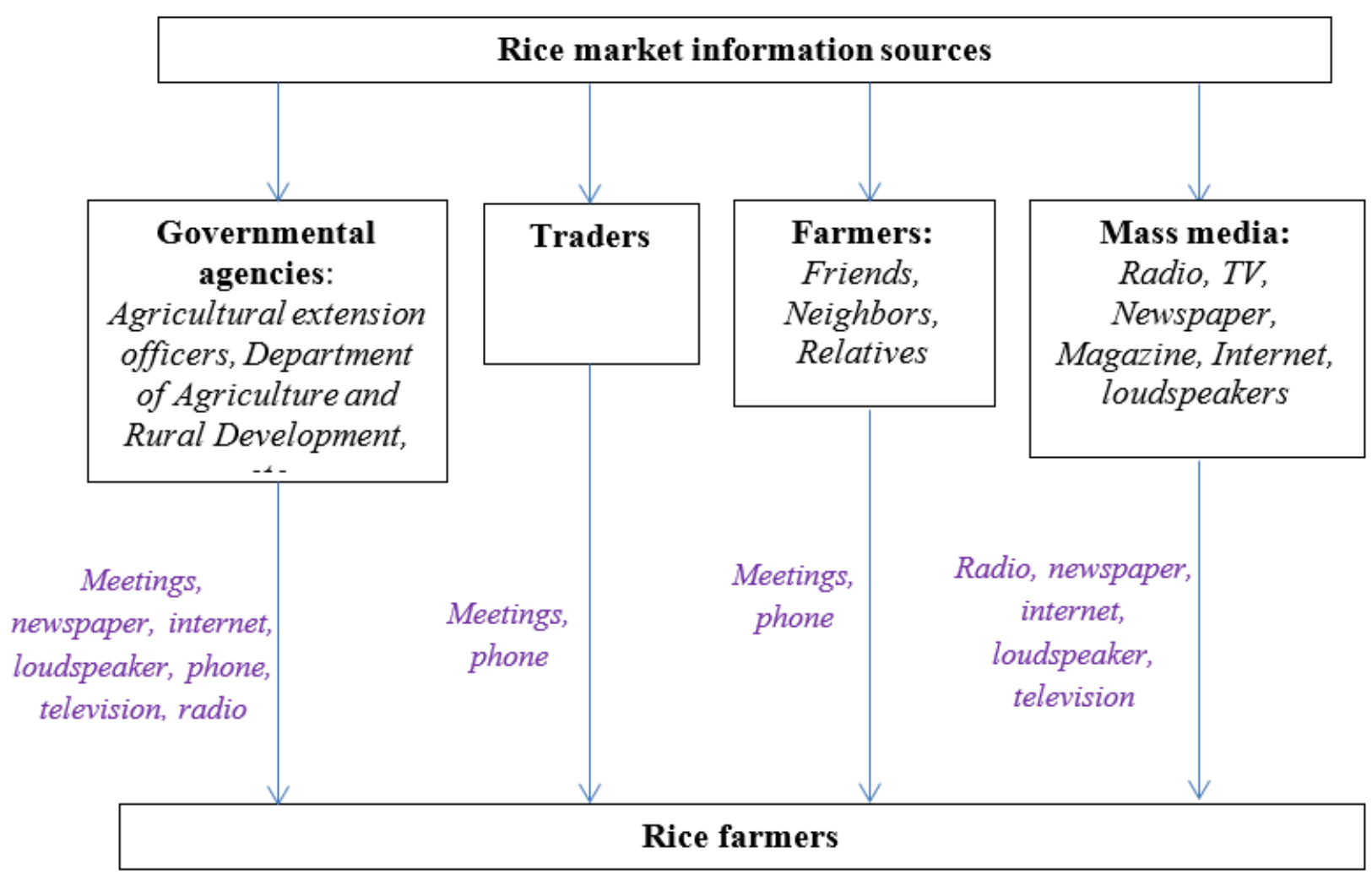

Figure 2: MITS in rice value chain in the Mekong delta, Vietnam

Source: Own survey, 2016

Farmers (friends, neighbors, relatives)

Rice farmers are the most important source because the market information was analyzed carefully, up-dated, and they do not hush up market information, they share all information they have and farmers can easily share market information because they are living in a village with a high population density.

There is an exchange of information about price among farmers. The market information from farmers is the most accurate. They got market information from many different sources and it is selected and analyzed. We can use this market information to bargain with traders (A farmer in Chau Phu district).

Besides market information from traders, the market information among farmers is also very important. In the process of living in the community, farmers have frequently met to share and discuss the market information with each other. The market information from other farmers is the best. They will share both good and bad news. The good news will help farmers sell rice with a higher price. The bad news will help farmers avoid disadvantages in bargains with traders (Director of Agricultural Extension Center).

Market information channels between farmers are face-to-face meetings and phone calls. The advantages of these channels are the fast speed of market information dissemination and low costs.

The disadvantages of this source are: Sometimes the quality of market information from farmers is not good because the process of collecting and sharing market information from farmers to farmers lasts for a long time, meanwhile the market change continuously, especially in harvest 
time. The quality of market information depends significantly on the analytical skills of farmers. If their above mentioned skills are weak, the quality is low and it will influence many farmers.

\section{Traders}

Rice traders in the Mekong delta have an important role in rice value chain because they are not only original source of market information but also market information providers. Currently traders are still keeping a big voice in bargaining with farmers so they will hush up or distort market information to farmers to get more profits.

Market information from friends is the best, meanwhile market information from traders is not good because they hush up or distort market information to eat profits from 2 sides: Farmers who sold rice to them and their sellers (bigger traders) (A farmer in Choi Moi district).

Farmers have been accessing to traders via 2 channels: Phone calls and face-to-face meetings. Advantages of this source are that they are very fast, up-dated information.

\section{Agricultural extension system}

In An Giang, only our Centre of Agricultural Extension is providing market information to farmers. We provid market information to farmers through 2 channels: Via website of An Giang Department of Agriculture and Rural Development and Agricultural Extension Paper of An Giang. Because of the lack of financial resources, we cannot transmit market information to many farmers via many channels (Director of An Giang Agricultural Extension Centre).

Agricultural extension system in An Giang has been providing market information to rice farmers via 2 channels, namely: website http://sonongnghiep.angiang.gov.vn/ and agricultural extension newspaper of An Giang. Market information on the website is updated every day from Monday to Friday after 10.00. In addition, agricultural extension Center of An Giang publishes agricultural extension newspaper of An Giang on every Friday with 1000 copies to introduce the market information (price information) of agricultural products, including rice every week.

The promotion department in Agricultural Extension Center of An Giang has a mission to get market information from agricultural extension stations of all districts and then it synthesizes and posts this market information on its website. In addition, on Friday the information about the price of all-day week is also synthesized to publish in Agricultural Extension Paper of An Giang (Director of An Giang Agricultural Extension Centre).

However, very few rice farmers could access to market information from agricultural extension system in An Giang because they haven't got internet and they did not access to newspaper either because of a small amount of copies. Meanwhile the agricultural extension system of An Giang lacks the budget and material facilities to provide market information to farmers. The budget for agricultural extension activities of An Giang Extensions Center per year was about 1,000,000,000 VND (about 50,000 USD), in which 200,000,000 VND (about 10,000 USD) (accounted for $20 \%$ of total budget of agricultural extension activities) was for providing market information to farmers.

I did not access to market information from governmental agencies because I didn't know where to access and how to access. I sometimes met the agricultural extension staffs at 
commune level, rarely I met extension staffs at the district level (A farmer in Choi Moi district).

\section{Mass media as a market information source}

Rice farmers in the Mekong delta have been sometimes accessing to market information from mass media such as television, internet, newspaper, loudspeaker, etc. However, television is the main source of market information in mass media for many farmers. Very few farmers used internet, newspaper, loudspeakers to get market information.

Market information from mass media is not useful, it is unspecific and inaccurate. I only concern information on rice export, export price, export to where, etc. If this information is good, it means that the rice price will also be good in the future and the opposite (A farmer in Thoai Son district).

Television:

Rice farmers in the Mekong delta used TV as a main source in mass media. They watched macro-information about rice export of Vietnam on TV to make good decisions in their production and trading.

I watched television such as VTV1, VTC16, An Giang TV, Vinh Long TV, Can Tho TV to gain the rice market information (A farmer in Chau Phu district).

The disadvantages of television are that the quality of market information is not good because the market information on television is collected and analyzed through a very large area and not frequently enough (Director of An Giang Agricultural Extension Centre). Secondly, the time of broadcasting on television was not suitable for farmers because the programs about market information were broadcasted in daytime when farmers were busy to work. Finally, the speed of information broadcast on television is too fast to keep a close watch and remember (Director of An Giang Agricultural Extension Centre).

Newspapers and magazines:

Rice farmers in the Mekong delta, Vietnam can access to market information from 2 newspapers: Vietnam Agriculture Newspaper and Provincial Agricultural Extension Newspaper. Respondents said that they did not read Vietnam Agriculture Newspaper because they need to have money to buy it. Provincial Agricultural Extension Newspaper was free for all readers but farmers could not also read it because the amount of newspaper was limited, only officials in commune and village could read it.

I didn't read newspapers to get market information because I don't have money to pay for them (A farmer in Thoai Son district).

I also saw that market information from newspaper was not good because the way to collect market information was not correct and the data reflected an average number of a large area. The information was not up-dated because that was a weekly newspaper.

Internet:

The number of internet users is increasing day by day in Vietnam but mainly in cities, towns. Farmer household rate with internet access in the countryside is still rather low. 
The survey showed that 2 out of 15 rice farmers are using internet to seek market information. Generally speaking, very few farmers used internet as a market information source because they need to buy a computer and internet paying monthly fee for internet and they also need to have skills to use computer and internet but Vietnamese farmers are lacking these skills.

I didn't use internet to take market information because I don't have money to pay for it (A farmer in Thoai Son district).

Loudspeakers:

An Giang is still maintaining the loudspeaker system in the countryside. It means that there are 1-2 loudspeakers in each village to broadcast information about economy, society, and politics of Vietnam or about the local news in early morning and late afternoon. Almost all farmers I interviewed said that they had not heard market information from loudspeakers but only one farmer said that he had sometimes heard market information from loudspeakers at harvest time.

The advantages of loudspeakers are that loudspeakers are very suitable for farmers, they can be easy to hear information from loudspeakers even when they are busy. Secondly, a big amount of farmers can hear information simultaneously from loudspeakers without a fee.

\section{Market information utilization}

Rice farmers in An Giang have been using market information in their production and trading. They used market information in building the next season plan, defining the selling prices: when to sell and whom to sell. They used information about prices of different rice varieties to grow a rice variety with a higher price for the next crop. They used macro-information such as the situation of rice export of Vietnam and rice export prices to decide on the investment or not. Farmers say that if they hear that the situation of rice export of Vietnam is good and rice export price is high they will increase investment in rice fields because normally the selling price of rice will increase and if rice sale is easy many traders will go to buy, otherwise, they will reduce the investment to decrease production costs and risks.

I used market information to define who I sell rice to with the highest price, when I sell, and what the selling price is (A farmer in Choi Moi district).

\section{Impacts of market information}

Market information had remarkable impacts on farmers. Interviewees reckoned that market information had 4 main influences on farmers: (1) Increased the selling prices of farmers; (2) Improved the rice income of farmers; (3) Reduced the risks in rice production and trade; (4) Changed the farmers' position in the value chains.

We used market information to bargain with traders to increase the prices and improve the rice income. ( A farmer in Cho Moi district).

One impact of market information is to increase the selling price of farmers. The market information helps farmers find buyers with high prices, bargain traders with good prices and help them grow rice varieties the market need to sell with higher prices. It means that they need to use market information harmoniously with their production and trading to maximize the profits. 
Rice revenue will depend on many factors, including selling prices so market information will help improve farmers' income from rice through the increasing of selling prices.

In addition, the market information helps farmers avoid risks, losses in their rice production and trade. With good market information rice farmers produce rice varieties that can meet the demands of markets to avoid overproduction (market risk) and reduce the investment in their rice production to reduce the production costs and losses (production risk) when rice prices go down.

Market information increases farmers' voice in rice value chain. With good market information they can bargain with traders to get higher prices to avoid disadvantages in bargaining. Farmers can sell rice with higher prices by $50-100 \mathrm{VND} / \mathrm{kg}$ compared to prices traders gave to them. Besides, during bargaining with traders, if they don't agree with a trader, they can easily find other traders to sell.

\section{Conclusions}

From the analysis above we can draw some main conclusions as follows:

MITS has an important role for rice farmers in the Mekong delta because market information remarkably influences their rice production and trading. Market information improved their selling price, profits, income and simultaneously reduced the risk, enhanced their position in rice value chain and in bargaining with buyers.

Farmers need both micro and macro information in market information. The micro market information includes the price of each kind of rice, where to sell, who to sell, the addresses of buyers, and the phone number of buyers in order to help them choose a good buyer with a high price. The macro market information contains information about the situation of national rice export, the demands of international markets and the prediction of international markets because the national rice export has a significant and direct effect on rice farmers in the Mekong delta, as $90 \%$ of national rice export amount has come from the Mekong delta.

Rice farmers have been accessing to 2 kinds of market information sources: Formal and informal. Formal sources are governmental agencies, television, radio, formal papers, etc. The informal sources are friends, relatives, other farmers, traders, internet, etc. However, in practice farmers have been mainly accessing to and using informal sources because these sources are easy to access with very low/no cost, they are speed but the quality of market information from these sources is not good, nobody manages and supervises these sources. Although the quality of market information from the formal sources is quite good but only few farmers have been accessing to and using these sources because the density of these sources is low and they need high costs to access to these sources. Also, the speed of market information transfer is so slow that the information is inadequate and no longer up-dated.

The main market information channels farmers have been accessing to are face-to-face meetings and phone calls. These are the favorite and convenient channels for farmers in the Mekong delta. The channels such as Internet, Television, newspapers, etc are used by few farmers because they are costly and the farmers' skills to use computers, internet, etc are not enough.

Rice farmers have used market information in their rice production and trade. The market information is used in building the next season plan: What kind of rice to grow and when to 
grow to sell with the highest price. The market information helps farmer modify their activities in rice production to reduce the risks. Farmers have been used market information to choose buyers and define the good selling price in their rice trading activities.

\section{References}

1. Edda Tandi Lwoga and et al (2010). Information needs and information seeking behaviour of small-scale farmers in Tanzania. Innovation, No.40, June 2010

2. Kehinde Oladele Joseph (2009). Integrated marketing communications and consumers patronage of Nigerian beverage products. $\mathrm{PhD}$. thesis at Covenant University, Nigeria.

3. Mária Bernschütz (2011). The Structural Model of the Application of Integrated Marketing Communications. Ph.D. dissertation at Corvinus University of Budapest

4. Mawazo M. Magesa, Kisangiri Michael and Jesuk Ko (2014). Agricultural Market Information Services in Developing Countries: A Review. ACSIJ Advances in Computer Science: an International Journal, Vol. 3, Issue 3, No.9 , May 2014

5. Saikia S.and Barman U. (2013). Market information sources utilised by farmers to improve their adoption decisions on sali rice technologies. J. Acad. Indus. Res. Vol. 1(10) March 2013

6. Sultan Freihat (2012). The role of marketing information system in marketing decision-making in Jordanian shareholding medicines production companies. IJRRAS 11 (2). May 2012. www.arpapress.com/Volumes/Vol11Issue2/IJRRAS_11_2_18.pdf

7. Surabhi Mittal and Mamta Mehar (2013). Agricultural information networks, information needs and risk management strategies: a survey of farmers in IndoGangetic Plains of India. Socioeconomics Working Paper 10. Mexico, D.F.: CIMMYT

8. Surabhi Mittal and Mamta Mehar (2013). Agricultural information networks, information needs and risk management strategies: a survey of farmers in IndoGangetic Plains of India. Socioeconomics Working Paper 10. Mexico, D.F.: CIMMYT

9. Tran Cong Thang, Do Lien Huong, Le Nguyet Minh (2013). Policy draft: Who benefits when the rice price increases? 